\title{
Early 19th Century Maltese Doctors in the Service of the Crown
}

\author{
Lt Col W Bonnici \\ MRCGP, DCH, RAMC
}

24 Armoured Field Ambulance, Gaza Barracks, Catterick Garrison, DL9 4AU

SUMMARY: The establishment of a British garrison in Malta in September 1800, provided opportunities for $\frac{}{\circ}$ Maltese doctors to join the Army Medical Department. This article follows the academic and military life of four $\overline{\bar{N}}$ Maltese practitioners, whose joint careers span the era of the Napoleonic Wars.

\section{Introduction}

The Maltese Islands were captured by Napoleon Bonaparte in June 1798. Three months later the inhabitants rose against the French and, assisted by British troops, liberated the islands. A succession of infantry regiments was subsequently raised for the defence of Malta. These, together with the British Naval Hospital, and the Garrison Hospital in Valletta, provided openings for young practitioners to seek army commissions. Amongst the first were Lorenzo Sammut, Joseph (Josiah) Schembri, Giuseppe Schembri, and Gavino Patrizio Portelli. Their careers give us an insight into the medical education and service life of army medical officers during the early nineteenth century.

\section{Assistant Surgeon Lorenzo Sammut}

The medical education embarked upon by Lorenzo Sammut in the late eighteenth century was the standard training for prospective surgeons. The customary qualification for a surgeon was the Membership of the Royal College of Surgeons. Sammut is the first recorded Maltese army surgeon to have gained such qualification. In 1794 he begun his surgical training at the Sacra Infermeria of the Order of St John of Jerusalem. Sammut studied anatomy under Michel 'Angelo Grima, the Senior Surgeon of the Order, and Professor of Anatomy and Surgery at the University of Malta. However his studies were disrupted by the French invasion of Malta when Napoleon expelled the Order and abolished the university. The Sacra Infermeria was exclusively reserved for French troops. Its civilian patients were transferred to the nearby convent of Mary Magdalen, which became known as the Civil Hospital for Men. After the expulsion of the French in September 1800, the University of Maita was reconstituted and the Civil Hospital for Men became its teaching hospital. Aurelio Badatt, the former Senior Surgeon of the naval squadron of the Order of St John, was appointed demonstrator in anatomy. Sammut recommenced his studies in 1800 and for the next six years attended the lectures and demonstrations in practical anatomy and practical surgery given by Badatt. In 1806 Sammut was appointed Warrant Hospital Mate to the British Naval Hospital in Valletta. In the army there were two classes of hospital mates, Warrant Hospital Mates for Temporary Service, and Commissioned Hospital Mates for General Service. The former were usually not highly qualified, as a certificate of attendance at a hospital for a year was all that was required. Warrant Hospital Mates were not eligible for a commission until they gained further? qualifications. In June 1813 the rank of Commissioned $\overrightarrow{\vec{\omega}}$ Hospital Mate was replaced by that of Hospital Assistant to $\omega$ the Forces, whereas those appointed by warrant retained the term Hospital Mate (1). In 1809 Hospital Mate Sammut 3 proceeded to London to obtain broader clinical experience. $\stackrel{?}{+}$ The medical education provided by the teaching hospitals $\vec{\omega}$ in London was primarily one of attendance at lectures. $)$ Surgical apprentices enrolled on courses of lectures at such teaching establishments as $\mathrm{St}$ Thomas's and $\mathrm{St}^{\vec{N}}$ Bartholomew's Hospitals, or at private schools such as the Great Windmill Street School of Anatomy run by WillianHunter, or that run by the former army staff-surgeon Jose 9 क्ष Constantine Carpue. Teaching on the wards was restrictefid to the copying of case notes, observing operations, åd following surgical dressers on their rounds. Surgeo $\stackrel{\vec{\theta}}{\vec{\theta}}$ frequently took on paying pupils, often accommodatieg them in their own homes as resident pupils (2). The. examination for membership of the Royal College \& $\mathrm{g}$ Surgeons consisted of a viva voce only. Students were nt required to show proficiency in operative surgery, but hado to prove attendance to a course of lectures on anatomy and surgery. A typical programme was that pursued by Lorenzo Sammut in 1809 (3). Over six months he attended clinical $\vec{O}$ lectures, concurrently with lectures on chemistry and 3 therapeutics given by the physician and chemist George Pearson at St George's Hospital, lectures on midwifery? given by Dr Andrew Thynne, and lectures in practical 3 anatomy, anatomy, physiology and surgery as a house pupil of the anatomist Joshua Brookes, whose museum of human and comparative anatomy was second only to that of John Hunter. Sammut became a member of the Royal College of $\underset{F}{\mathscr{Q}}$ Surgeons on 14 December 1809 . The fee payable for a? licence to practise surgery outside the city of London 3 amounted to fifteen guineas. Having passed the examination of the Army Medical Board and the Royal $\frac{\circ}{3}$ College of Surgeons of London, Sammut was commissioned Hospital Mate for General Service on 4을 January 1810 . He had to pay a fee of $£ 5-7 \mathrm{~s}-6 \mathrm{~d}$ towards the $\frac{7}{0}$ cost of his commission (4). This was quite a substantial sum considering that the daily rate of pay of a Hospital Mate $N$ was $6 \mathrm{~s} 6 \mathrm{~d}$ at home and $7 \mathrm{~s} 6 \mathrm{~d}$ abroad. Hospital Mate Sammut was taken on the strength of the army recruiting depot at Newport, Isle of Wight, and worked at Hilsea ${ }^{\omega}$ Barracks near Portsmouth. He returned to Malta and in 
June 1811 was on the staff of the Garrison Hospital Valletta. On 22 August, Sammut was appointed Assistant Surgeon to the Royal Corsican Rangers, and moved to the Ionian Islands (5). On the formation of the 2nd or Duke of York Greek Light Infantry he became surgeon to that regiment according to a General Order, dated Zante, 4 April 1814. The Duke of York Light Infantry and the Royal Corsican Rangers were eventually disbanded and Sammut accompanied the discharged men to their homes in Messina, Naples and Genoa. On 30 January 1817, Assistant Surgeon Lorenzo Sammut was relegated to half pay, having served just under eight years. He retumed to Malta and obtained a position as a surgeon to the Civil Hospital in Valletta.

\section{Apothecary to the Forces Joseph (Josiah) Schembri}

The apothecary or druggist was regarded as nothing more than a shopkeeper by his professional brethren. His education was wholly practical consisting of an apprenticeship to a senior apothecary. By the early part of the nineteenth century the apothecary had become the established general medical practitioner. In the army, the apothecary was a staff medical officer placed in charge of the medicines and medical stores of a general hospital. He was selected from the hospital mates or assistant surgeons and paid a salary of ten shillings a day. The rank of Apothecary to the Forces was abolished by the Royal Warrant of 29 July 1830 . Joseph Schembri was born on 2 April 1787. He was just sixteen years old when he began a two year apprenticeship to Mr G M Grech, Apothecary to the City of Valletta. In 1804 he attended the Civil Hospital and over eighteen months followed the lectures in anatomy, physiology and the practice of surgery given by Aurelio Badatt. At nineteen years of age, Joseph Schembri was examined by a Medical Board held in Sicily on the orders of the Inspector of Hospitals William Franklin, Head of the Medical Staff in the Mediterranean. He also passed an examination held before the Army Medical Board and the committee of the Royal College of Surgeons of London, and on 17 January 1807 was appointed Warrant Hospital Mate (6). He was afterwards employed at the General Hospital Messina. Meanwhile, Napoleon had secured total dominance over Europe. In an attempt to cripple England, Napoleon imposed an embargo on British goods. Lisbon refused to close her ports to British shipping. France invaded Portugal, but on 29 November 1807, the Portuguese Court fled to Brazil. An expedition under LtGeneral Sir John Moore left Sicily to secure the Portuguese fleet and assist the court in their departure. Hospital Mate Schembri embarked with the army on 25 October. However, the expedition was delayed by atrocious weather, and by the time it reached Gibraltar on 1 December, Moore's mission had become superfluous (7). Schembri disembarked at Gibraltar and returned to Messina in April 1808.

On 9 April 1809, Austria began the War of the Fifth Coalition against France, but was defeated by Napoleon at Wagram on 6 July. To assist her allies, Britain launched diversionary attacks against Napoleon's naval base at Antwerp and on the Kingdom of Naples. An expedition under Lt-General Sir John Stuart left Milazzo, Sicily, and headed towards the Gulf of Naples. On 25 June, Stuart attacked the islands of Ischia and Procida (8). Schembri was present at both sieges, but as Ischia was taken with very little resistance and the garrison of Procida surrendered during the day, his task could not have been arduous. After two months on this futile expedition, the army under Stuart returned to Milazzo. Hospital Mate Schembri took charge of the medical stores of the garrison, and remained at Milazzo for the following eighteen months. On 25 June 1812, Schembri accompanied a diversionary expedition to the east coast of Spain. An Anglo-Sicilian force under Lt-General Frederick Maitland was to threaten Catalonia so as to prevent Marshal Suchet from reinforcing Marshal Marmont's Army of Portugal (9). After many unavoidable delays the troops reached the coast of Catalonia towards the end of July and landed at Alicante on 9 August.

While at the General Hospital at Alicante, Hospital Mate Schembri was appointed Commissioned Hospital Mate on 28 December 1812 , and on 14 October 1813 was promoted Apothecary to the Forces (10). He served in Spain until 1814 , when he embarked on yet another diversionary expedition. Major General Lord William Bentinckळ commander of the army of the Mediterranean in Sicilya assembled his army at Milazzo and Palermo. In the hope of tying down a large part of the French army in Naples, Bentinck decided to capture Corsica. He later altered his plan in favour of a landing on the Italian mainland. The army arrived at Leghorn on 10 March, but as Genoa waso perceived to be lightly garrisoned Bentinck launched an attack against the town (11). Apothecary to the Forces Joseph Schembri was present at the siege and capture of Genoa on 17 April 1814. Inspector of Hospitals James Borland, Head of the Medical Department in the Mediterranean, then instructed him to return with the medical stores from Genoa to Sicily.

In the interim Napoleon had abdicated and had been exiled to Elba. He escaped from Elba, but his defeat at Waterloo on 18 June 1815 finally concluded the Napoleonic wars. At the ensuing Congress of Vienna, England agreed to withdraw her troops from Sicily and in June 1815 the Kingdom of the two Sicilies, incorporating Naples and Sicily, was reconstituted. Following the evacuation of Sicily, Apothecary to the Forces Schembri moved to Corfu to take charge of the stores of the Ionian Islands (12). On 25 April 1816, he was relieved by Apothecary to the Forces Edmund Starkie, and embarked for England in charge of invalids.

Joseph Schembri was discharged on half pay on 25 August 1816. He was then 29 years old. While on half pay, he spent twelve months at St Georges' Hospital London and four months at the Duke of York Hospital, Chelsea, preparing himself for the examination of the Royal College of Surgeons. In 1816 he attended a twelve month course of lectures in Anatomy, Physiology and Surgery given by the 
surgeon and anatomist J C Carpue, and the following year took a four month course of lectures in chemistry given by William Thomas Brande, and a further four months' lectures in the Principles and Practice of Surgery given by George James Guthrie. He became a member of the Royal College of Surgeons of London on 2 May 1817. In the first half of the nineteenth century France was the undisputed leader in medical education and many students continued their studies there. Schembri enrolled at the Hotel Dieu Hospital in Paris, and in 1818 took a ten month course of lectures in the Practice of Medicine given by Dr Larroque. On 26 August 1826, Apothecary to the Forces Joseph Schembri married at Messina, Sicily, and took up home in that town. However, on 13 March 1835, aged forty-eight years he was recalled to full pay and sent to the Ionian Islands. He retired on half pay on 21 September 1860 , at the venerable age of 73 years (13).

\section{Assistant Surgeon Giuseppe Schembri}

The military service of Giuseppe Schembri was plagued with misfortune, as almost every regiment he joined was disbanded. In a way his career reflected the turbulent age in which he lived. He was born around 1771, at a time when the Order of St John of Jerusalem was struggling for its very survival. Little is known about his medical education other than that he had attended the hospitals at Malta and had studied and taken a degree at the University of Naples (14). At the relatively advanced age of thirty years, Giuseppe became Assistant Surgeon to the Maltese Light Infantry. This regiment had been raised by Brigadier Thomas Graham in May 1800 to reinforce the 30th and 89th Foot during the blockade of the French in Malta. The Maltese Light Infantry was disbanded in April 1802. Thus, when Giuseppe took up his appointment on 15 September 1801 , its days were already numbered. Although the regiment was raised to serve only in Malta, it was called upon to reinforce the besieged British garrison at Porto Ferrajo in Elba. On 22 September Giuseppe accompanied 200 volunteers to Elba. He reached the island on 11 October (15), In the meantime, the French Army of the East had been expelled from Egypt in September 1801, and British troops under Major General John Stuart occupied Alexandria. The Preliminary Articles of Peace bringing the French Revolutionary Wars to an end had been signed on 1 October 1801. Elba was ceded to France and the Maltese Light Infantry returned to Malta. The regiment was disbanded, and the men discharged. Giuseppe found alternative employment with the British garrison in Egypt. He left Malta for Alexandria on 3 November 1802. However, the Treaty of Amiens returned Egypt to the Ottoman Empire, and in March 1803 the British garrison was withdrawn. After his return to Malta, Giuseppe entered into the state of matrimony on 26 April 1804, and had a son, Anthony, born on 10 February 1805 (16).

Hostilities between England and France resumed in May 1803. Britain retained Malta. Among the foreign corps stationed on the island was one raised by Count Mountjoy Froberg. On 25 April 1806, Giuseppe Schembri was appointed Assistant Surgeon to Froberg levy by Inspecto of Hospitals Franklin. The soldiers of Froberg levy who hads enlisted at Constantinople and Albania felt themselve: extremely aggrieved by the fraudulent way in which they were recruited, having been lured by false promises anf extravagant descriptions of the pay and allowances (17)? The men had also been confined for a long time in For $\vec{F}$ Ricasoli because of serious disturbances between them and the inhabitants. On 4 April 1807, a group of dissatisfied Greeks and Albanians killed their adjutant and demanded passage to Corfu. They compelled others to join the mutiny but the Poles and the Germans escaped by forcing open the gate of the fort. A hard core of mutineers refused to layes down their arms and, on the night of 12 April, blew $\overrightarrow{0}$ themselves up in the powder magazine. Froberg levy wasdisbanded, and while awaiting another appointment Giuseppe Schembri did duty at the Garrison Hospitat Valletta. Eventually Thomas Keate, who as Surgeon General appointed the surgeons and assistant surgeons to? regiments, recommended that Giuseppe Schembri shoulds be examined in medicine and surgery at Malta, and, if successful, appointed Assistant Surgeon to the Royati Regiment of Malta (18). Giuseppe Schembri waș commissioned Assistant Surgeon on 10 September 18070 The Royal Regiment of Malta was raised on 30 Maroh 1805, and placed on the strength of the British Army. Oro November 1807 it joined the army in Sicily and ainf September 1808 was ordered from Milazzo to Ca Unfortunately on 4 October 1808 , within a fortnight of कृts arrival at Capri, almost the whole regiment was captured the French (19). Giuseppe was held prisoner-of-waroat Castel Nuovo near Naples until his release on 11 Februa flo 1810. Following its debacle at Capri, the Royal Regiment of Malta failed to recruit and was disbanded on 26 Aprif 1811 (20). Assistant Surgeon Giuseppe Schembri wa ô discharged on half pay. He was now forty years and in vievg of his age did not seek further military posts. However, he remained in practice and gratuitously gave his services during the outbreak of plague in Malta in 1813. He died on 14 March 1835.

\section{Assistant Surgeon Gavino Patrizio Portelli}

The formative years spent by Gavino P Portelli in the army were to serve him well. After his military careers Portelli became an eminent member of the Maltese medica迎 profession, served on various Health Commissions, an $\overline{\vec{F}}$ ultimately occupied the Chair of Anatomy and Surgery as the University of Malta (1822-1838).

Portelli was born in Valletta on 16 March 1795. At the young age of thirteen he started an eighteen month course of lectures in anatomy given by the surgeon Francescos Buttigieg and a four year apprenticeship to Joseph Portellis Apothecary to the Garrison Hospital (21). Joseph Portelli is the earliest Maltese practitioner to appear on the staff of the Garrison Hospital, being first listed in the returns of $f$ March 1807 (22). On 25 March 1809, Gavino Portelli was granted a warrant as a Dispenser of Medicines to thew Garrison Hospital (23). He was then only 15 years old. The 
Dispenser of Medicine was authorised to work under the immediate supervision of the apothecary. He received a salary of five shillings a day. It is noteworthy that Hospital Mate Lorenzo Sammut MRCS served at the Garrison Hospital at this time (24). Portelli would undoubtedly have gained first hand information from Sammut about life as a medical student in London. In fact, in July 1812, Portelli obtained leave to study at Westminster Hospital and at Duke of York Hospital. In London, he took a fourteen month course of lectures in anatomy, physiology, and surgery given by J C Carpue, and for four months attended the lectures on chemistry given by the physician John Ayrton Paris. The following year, he enrolled on a four month course of lectures on the theory and practice of Physic given by Robert Hooper, and on materia medica and chemistry given by Joseph Ager. As he had not yet reached the age of twenty-two he was ineligible to sit for the membership of the Royal College of Surgeons. However, he passed the examination held before the Army Medical Board composed of John Weir, Charles Ker and William Franklin and was approved by the committee of the Royal College of London. On 6 September 1813 he was commissioned Hospital Assistant Surgeon (25). His pay was $7 \mathrm{~s}-6 \mathrm{~d}$ a day, but $£ 4-19 \mathrm{~s}-6 \mathrm{~d}$ was first deducted as a fee towards his commission. On 26 November 1813 Portelli received his embarkation orders to join the expedition of General Thomas Graham to Holland, and reported to Inspector of Hospitals James Robert Grant, the Principal Medical Officer (26). Portelli embarked at Ramsgate on 9 December. The main objective of Graham's expedition was to capture Antwerp, but at the storming of Bergen-op-Zoom on 8 and 9 March 1814, Graham's force was repelled with heavy losses (27). Four surgeons were taken prisoners by the French, and Portelli is said to have been lightly wounded (28). He was fit enough, though, to accompany the wounded men of the different regiments to York Hospital. From there, he joined the depot at the Isle of Wight and did duty at Albany Hospital. On 26 May 1814, Portelli was commissioned Assistant Surgeon to the Second Battalion 10th Foot. He embarked at Portsmouth on 20 September and arrived at Malta on 25 October. While on board the transport vessel, Dartmouth, he was charged $3 \mathrm{~d}$ a day towards his rations, whereas on shore his stoppages for provisions was $21 / 2 \mathrm{~d}$ per day (29). The First and Second Battalions 10th Foot were amalgamated on 23 January 1816, and Assistant Surgeon Portelli was discharged on half pay. In February 1816, Portelli completed his studies in London. He attended three courses of lectures in midwifery given Dr Samuel Merriman, and on 3 May became a Member of the Royal College of Surgeons, London. On 8 August 1816 Portelli was appointed Assistant Surgeon to the First Battalion 10th Foot. He joined the regiment in Corfu and on 30 August 1817 was transferred to the Military Hospital at Zante. Assistant Surgeon Portelli returned to Malta on 29 November 1818, and was discharged on half pay on 24 March 1819. He died in Malta on 7 January 1865 , after a prolonged illness.

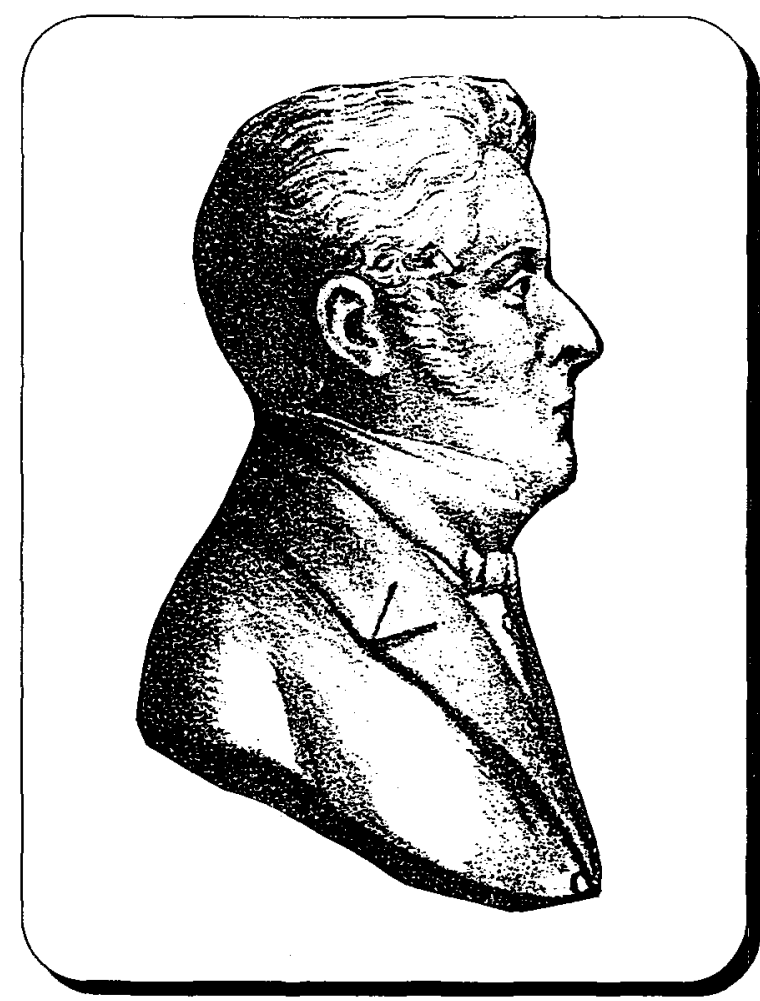

Gavino Patrizio Portelli (1795-1865) (From L'Arte 1865)

\section{Epilogue}

Although Lorenzo Sammut, Joseph Schembri, Giuseppe Schembri, and Gavino Patrizio Portelli were not the only Maltese surgeons to serve with the army, their military careers were fairly representative of medical officers during the Napoleonic wars. Relegation to half pay always threatened to cut short a promising army career, but the expertise they gained on the battlefield served them well in their civilian work. In Britain, former military surgeons such as JC Carpue and GJ Guthrie had distinguished civilian careers in medical education. In Malta Lorenzo Sammut became Principal Surgeon to the Civil Hospital in Valletta. Gavino Portelli, as Professor of Anatomy and Surgery, established an anatomical theatre at the same hospital and guided the training of many a young Maltese practitioner.

\section{REFERENCES.}

Documents cited at Public Record Office

1. WO 7/108, Circular 8 June 1813 PMO letter book Mar 1812 - Feb 1814.

2. FORD JMT. A medical student at St Thomas's Hospital, 1801-1802. The Weekes. Family papers. Med Hist Supp No 7, 1987. Wellcome Institute London 1987.

3. WO $25 / 3905$, f159. Returns of service and professional education.

N 
4. WO 4/514, War Office letter 19 Mar 1810.

5. WO $7 / 109$, Appointments on the medical staff of the army in the Mediterranean.

6. WO $25 / 773$, f70 Returns officers on half pay rendered under the circular letter 22 October 1828.

7. WO $1 / 305,4$ Dec 1807 Moore to Castlereagh.

8. WO $1 / 307,5$ Jul 1809 Stuart to Castlereagh.

9. WO $1 / 316,24$ Jul 1812 Maitland to Liverpool .

10. WO $25 / 3906$, f128.

11. WO $1 / 315,20$ April 1814 Bentinck to Bathurst

12. WO 25/3901, f964,

13. Drew: Medical Officers in the British army 16601960. Vol I: 1660-1898 Peterkin and Johnston. Wellcome London 1968.

14. WO 1/293, f209 29 May 1806 Franklin to Villettes.

15 . WO $1 / 292,22$ Sep 1801 Villettes to Hobart.

16. WO $25 / 773$, f64.
17. WO $1 / 293,9$ April 1807 Villettes to Fox.

18. WO 4/402, f506 8 SEP 1806 Moore to Gordon.

19. WO $1 / 306,31$ Oct 1808 Stuart to Castlereagh.

20. CO 157/17, 25 April 1811 Oakes to Liverpool.

21. WO $25 / 3906$, f110.

22. WO 17/2123, Returns officers of the hospitals in Malta for 1 March 1807.

23. WO $5 / 771$, f153.

24. WO $17 / 2125$, Returns officers of the hospitals in Malta for 25 June 1811 .

25. WO $25 / 3906$, f110.

26. WO 7/108, f358 26 Nov 1813 AMD to Grant.

27. WO $1 / 200$, f117 10 March 1814 Graham to Bathurst .

28. ZAMMTT N. L'Arte 1865 Vol III n 63 pp 3-5. Obituary Gavino P Portelli.

29. WO $12 / 2818$, Regimental pay list 2/10th Foot 18131816. 